\title{
Expression of a bacterial xylose isomerase in an industrial strain of Saccharomyces cerevisiae
}

\author{
Beatriz Temer ${ }^{1 *}$, Leandro Vieira Santos ${ }^{2}$, Luige Armando Calderón², Gonçalo Amarante Guimarães Pereira ${ }^{2}$ \\ From 5th Congress of the Brazilian Biotechnology Society (SBBIOTEC) \\ Florianópolis, Brazil. 10-14 November 2013
}

\begin{abstract}
Background
The use of lignocellulosic biomass rather than fossil fuel is an environmental sustainable alternative for bioethanol production. However, fermentation of lignocellulosic hydrolysates by Saccharomyces cerevisiae is not viable since this yeast cannot ferment xylose naturally. Current, several studies are being developed to introduce a pathway that allows pentose fermentation by $S$. cerevisiae [1]. The bacterium Propionibacterium acidipropionici, employed in many industrial processes, is able to efficiently ferment xylose using the enzyme xylose isomerase. Xylose isomerase, codified by the XI gene, converts xylose to xylulose [2]. This study aims to develop a yeast capable of fermenting xylose through the expression of the $P$. acidipropioniciXI gene in S. cerevisiae. Furthermore, the effect of the over expression of a gene that encodes a xylulokinase (XKS1) and the deletion of the gene that codifies an aldose reductase $(A R)$ together with the expression of the $X I$ gene were evaluated. These enzymes are crucial for xylose fermentation since the former converts xylulose to xylulose-5-P by the pentose phosphate pathway (PPP) and the last converts xylose into xylitol, which can alter the xylose isomerase activity [3].
\end{abstract}

\section{Methods}

The sequence of the $X I$ gene from $P$. acidipropionici was obtained from its genome recently published [4]. An industrial strain of $S$. cerevisiae derived from PE-2, A1

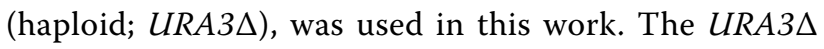
was used as an auxotrophic mark to select the transformants. The strategy chosen for heterologous expression of the $X I$ gene by S. cerevisiae was its introduction in a high copy number plasmid. This plasmid contains the $U R A 3$ gene and the $X I$ gene was cloned with a

'Universidade Estadual de Campinas, UNICAMP, Campinas, SP, Brazil Full list of author information is available at the end of the article constitutive promoter and terminator. Three strategies were used to evaluate the heterologous expression of the $X I$ gene: (1) expression of the $X I$ gene alone; (2) expression of the XI and overexpression of the XKS1 gene; (3) expression of the $X I$ gene, overexpression of $X K S 1$ and deletion of the $A R$ gene.

\section{Results and conclusion}

Tests of growth performed in a culture medium supplemented with xylose proved the great ability of $P$. acidipropionici to grow in this carbon source. Considering that the codon usage of $S$. cerevisiae is substantially different from the $P$. acidipropionici and given that this bacterium has a high GC content, an optimization of the codons from the $X I$ gene was performed. By this way, the codon adaptation index (CAI), initially 0.49 , raised to 0.93 after the optimization. The optimized gene was synthetized and the yeast was transformed with the $X I$ cassette. Preliminary fermentation tests in medium containing xylose as carbon source showed that these yeasts were still not able to ferment xylose. Analysis of RNA samples from all lineages confirmed that the $X I$ is expressed. Since the majority of the $X I$ sequences are protected by patents and the gene from this bacterium is not protected, many efforts are being done to understand the reason why this bacterial gene is not functional in S. cerevisiae.

\section{Acknowledgements \\ Fundação de Amparo à Pesquisa do Estado de São Paulo (FAPESP) and Laboratório de Genômica e Expressão (UNICAMP).}

\section{Authors' details \\ ${ }^{1}$ Universidade Estadual de Campinas, UNICAMP, Campinas, SP, Brazil. ¿Universidade Estadual de Campinas, UNICAMP, Laboratório de Genômica e Expressão, LGE, Campinas, SP, Brazil.}

\section{Published: 1 October 2014}




\section{References}

1. Cai Z, Zhang B, Li Y: Engineering Saccharomyces cerevisiae for efficient anaerobic xylose fermentation: reflections and perspectives. Biotechnology Journal 2012, 7(1):34-46, doi:10.1002/biot.201100053.

2. Carrondo MJT, Crspo JPSG, Moura MJ: Production of Propionic Acid Using a Xylose Utilizing Propionibacterium. Applied Biochemistry and Biotechnology 1988, 17(1-3):295-312.

3. Kuyper M, Winkler A, van Dijken JP, Pronk JT: Minimal metabolic engineering of Saccharomyces cerevisiae for efficient anaerobic xylose fermentation: a proof of principle. FEMS Yeast Research 2004, 4(6):655-64, doi:10.1016/j.femsyr.2004.01.003.

4. Parizzi LP, Grassi MCB, Llerena LA, Carazzolle MF, Queiroz VL, Lunardi I, Zeidler AF, Teixera PJPL, Mieczkowski P, Rincones J, Pereira GAG: The genome sequence of Propionibacterium acidipropionici provides insights into its biotechnological and industrial potential. BMC Genomics 2012, 13(562), doi:10.1186/1471-2164-13-562.

doi:10.1186/1753-6561-8-S4-P222

Cite this article as: Temer et al:: Expression of a bacterial xylose isomerase in an industrial strain of Saccharomyces cerevisiae. BMC Proceedings 2014 8(Suppl 4):P222.

\section{Submit your next manuscript to BioMed Central} and take full advantage of:

- Convenient online submission

- Thorough peer review

- No space constraints or color figure charges

- Immediate publication on acceptance

- Inclusion in PubMed, CAS, Scopus and Google Scholar

- Research which is freely available for redistribution

Submit your manuscript at www.biomedcentral.com/submit
C Biomed Central 